$\begin{array}{ll} & \text { Etnográfica } \\ \text { etnográfica } & \text { Revista do Centro em Rede de Investigação em }\end{array}$

Antropologia

vol. 23 (1) | 2019

Vol. $23(1)$

\title{
From Goa to Rabin Square: notes for a research on the uses and meanings of psychedelic trance music and parties in Israel
}

De Goa à Praça Rabin: notas para uma investigação sobre os usos e significados das festas de trance psicadélico em Israel

\section{Giorgio Gristina}

\section{(2) OpenEdition}

\section{Journals}

Electronic version

URL: https://journals.openedition.org/etnografica/6557

DOI: 10.4000/etnografica.6557

ISSN: 2182-2891

\section{Publisher}

Centro em Rede de Investigação em Antropologia

Printed version

Date of publication: 1 February 2019

Number of pages: 221-239

ISSN: 0873-6561

\section{Electronic reference}

Giorgio Gristina, "From Goa to Rabin Square: notes for a research on the uses and meanings of psychedelic trance music and parties in Israel", Etnográfica [Online], vol. 23 (1) | 2019, Online since 21 March 2019, connection on 20 January 2022. URL: http://journals.openedition.org/etnografica/6557 ; DOI: https://doi.org/10.4000/etnografica.6557

\section{(c) (†) \&}

Etnográfica is licensed under a Creative Commons Attribution-NonCommercial 4.0 International License. 


\section{From Goa to Rabin Square: notes for a research on the uses and meanings of psychedelic trance music and parties in Israel}

\section{Giorgio Gristina}

Psytrance or Psychedelic trance music was born at the end of the 1980s within the "full moon parties" organised by a temporary community of international travellers who settled on the beaches of the state of Goa, in southern India. From there it spread all around the world, creating a network of thousands of people, who've regularly gathered in events ranging from small clandestine parties in remote locations to big international festivals. Parties are focused on music and dance, yet characterised by a sort of syncretic spirituality, a pacifistic rhetoric and an environmental attitude, and often include the use of psychoactive substances. In Israel - where this phenomenon has reached an exceptional degree of participation and diffusion - psytrance first arrived via the numerous young people who went backpacking for some months after the compulsory military service, often directed to India. Few scholars dealt with the topic so far, and most of them connected the remarkable spread of psychedelic parties with the particular condition of prolonged conflict and militarisation which characterises the growth of the majority of Israel-born youth. This article - based on a recently started research project - aims to offer an overview of the theme, intersecting the little existing literature with the empiric material collected so far, presenting some possible interpretations and addressing a series of questions to be further investigated.

KEYWORDS: Israel/Palestine, Goa, psychedelic trance, rave, conflict, army.

De Goa à Praça Rabin: notas para uma investigação sobre os usos e significados das festas de trance psicadélico em Israel - O género de música conhecido como psytrance ou psychedelic trance nasceu no fim dos anos de 1980 nas "festas de Lua cheia" organizadas por uma comunidade temporária de viajantes internacionais que se formou nas praias de Goa, na Índia meridional. A partir dali, difundiu-se pelo mundo inteiro, criando uma rede de milhares de pessoas que se encontram regularmente em eventos tão diferentes como pequenas festas clandestinas em lugares remotos ou grandes festivais internacionais. As festas são focadas na música e na dança, mas são também caraterizadas por uma retórica orientada para temáticas espirituais, pacifistas e ecologistas, e incluem com frequência o uso de substâncias psicoativas. A psytrance chegou a Israel - onde o fenómeno atingiu um grau excecional de participação e difusão - através dos numerosos jovens que viajavam durante vários meses logo após o fim do serviço militar obrigatório, muitas vezes dirigindo-se para a Índia. Poucos autores abordaram o assunto, e a maioria deles relacionaram a notável difusão das festas psicadélicas com a condição particular de conflito prolongado e militarização intensiva que caracterizam o crescimento 


\begin{abstract}
da maioria dos jovens nascidos no Estado de Israel. Este artigo, baseado numa pesquisa começada recentemente, visa propor uma visão global do assunto, cruzando a restrita literatura existente com os dados empíricos recolhidos até agora, e apresentar algumas interpretações possíveis, assim como questões que precisam de ser ulteriormente investigadas.
\end{abstract}

PALAVRAS-CHAVE: Israel/Palestina, Goa, trance psicadélico, rave, conflito, exército.

GRISTINA, Giorgio (gio.grist@gmail.com) - Instituto de Ciências Sociais, Universidade de Lisboa (ICS-ULisboa), Portugal.

\title{
INTRODUCTION
}

This article is based on an ongoing research project which started in 2013 during the shooting of the documentary The Loudest Place on Earth, produced by BabyDoc Film and funded by the Torino Film Commission. Unfortunately, the film was never finished due to the sudden death of director and long-time friend Alessandro Baltera in August 2014. The film followed the story of a girl who was starting her compulsory military service and was deeply involved in what is known as psytrance or psychedelic trance parties. The first contact with people in the field was established with these filming purposes, and lead to the creation of an important relation with R., who was to be the protagonist of the movie, along with her group of friends. My interlocutors during the research were mostly young people (between 18 and 24 years of age) born and raised in Israel who were doing or had recently finished their period of compulsory military service, and were in the meantime engaged in a more or less constant participation in the psychedelic community. ${ }^{1}$

The research evolved into a PhD project hosted by ICS (Universidade de Lisboa, Portugal), whose main objective is to examine the relation between the practices associated with psychedelic trance music and the everyday experience of young soldiers in the military service in Israel. Given the embryonic

l The first and ultimately sole shooting session of the movie took place between May and June 2013. Our film crew was composed by three people from Italy with some previous knowledge of the psychedelic trance phenomenon, but not personally involved in any of its practices. None of us spoke Hebrew and, except for the director, it was our first visit to Israel. During eight weeks, we attended around ten psytrance events, including the biggest open-air festival held yearly in Israel (Indigo Festival), a couple of small clandestine parties in the Negev desert and a few different nights in clubs and venues in Tel Aviv, Haifa and Be'er Sheva. Between one event and the other, we tried to constantly keep in touch with the people we met at parties, sharing many different moments of their everyday life. All data collected, which then served as the basis for my MA dissertation (Gristina 2015), resulted from informal conversations or unstructured interviews, always conducted in English and sometimes filmed and/or sound recorded. 
stage of the project, which still lacks a second prolonged period of fieldwork, this article is presented as a collection of research notes, whose main aim is to provide an overview of the topic and to trace some possible paths to be explored, being therefore essentially a descriptive work, not directly dealing with theoretical issues. Moreover, the scientific literature on the topic is quite limited, so my revision will focus on the few authors who investigated and wrote on this particular topic: Graham St. John (2004, 2010, 2012a, 2012b), Bryan Meadan (2006), Joshua Schmidt (2010, 2012) and Elinor Carmi (2013a, 2013b, 2013c).

In the following paragraphs, I will first contextualise briefly the phenomenon of psychedelic trance parties, tracing its roots in Goa and following its arrival in Israel; I will then present the most relevant interpretations of the phenomenon given by scholars, thus sketching a sort of state of the art of the literature on the topic; consequently, I will give account of a case study which emerged from my observations, trying to see how it relates to these interpretations; finally, I will draw some conclusions and reflect on a series of questions that emerged from this analysis and need to be further investigated.

\section{FROM GOA TO RABIN SQUARE: A BRIEF HISTORY OF PSYTRANCE}

The music known today as psytrance or psychedelic trance ${ }^{2}$ was born at the end the 1980s within the "full moon parties" organised by a temporary community that had formed since the 1960s in the state of Goa, in southern India, thanks to the arrival of thousands of travellers and hippies, ${ }^{3}$ mainly from Europe and the United States. Carrying with them the particular mixture of electronic sounds and syncretic spirituality which distinguished the parties held among the palm forests of Anjuna and Vagator, and reproducing a similar format in many other countries, some of these young travellers slowly gave rise to an international network that today involves thousands of people, connected through hundreds of websites, blogs and social media. ${ }^{4}$

2 In Israel, people refer to the phenomenon here examined with the terms "trance" or "psytrance," or with the abbreviation "psy." The term mesiba (plur. mesibot), meaning "party," is used to refer to a single event, and the term trancist (plur. trancistim) to refer to party goers and organisers.

3 Hippie is a category commonly used in many different countries, yet it is still controversial to properly define it on a scientific basis. The term first emerged to indicate the young people living in New York City's Greenwich Village and San Francisco's Haight-Ashbury districts in the 1960s, who, inspired by the poets and writers of the so-called Beat Generation, started to self-proclaim themselves as a "counterculture": a group of people who refused what they considered as the common values of the US society. The first deep ethnographic account about hippies in the UK and US can be found in Willis (2014 [1978]).

4 Insiders usually refer to psytrance in terms of a "culture," and so do some scholars. Other researchers and journalists have alternatively used the terms "subculture," "movement" or "community". Although these terms sometimes appear in this article when citing other authors, I prefer to use [continues] 
People from diverse social and economic backgrounds participate in the phenomenon worldwide, with different degrees of involvement, ranging from an occasional appearance to a regular commitment (especially in the case of event organisers, DJs and music producers). Some of the most dedicated psytrancers can travel regularly to attend events, which can be as diverse as small clandestine parties in remote locations or huge festivals, one of the largest of the world being the Boom Festival, held every two years near Idanha-a-Nova, Portugal, and attracting around 40,000 people each edition.

Even if they took different forms over time, most of the psytrance parties held around the world still share the common characteristics of the rave party, ${ }^{5}$ being essentially centred around music and dance, and thus generally built around a sound system and a dance floor equipped with lights and decorations, which represents the main meeting area of the event. Parties usually last some days, thus frequently include a camping area or some other spaces dedicated to accommodation and rest, as well as food sellers. Equally common is the presence of stalls trading different types of artisanal products (clothing, jewels, accessories, etc.). Bigger events started to incorporate more activities such as performances, workshops, conferences, massages, different types of therapeutic practices, and the like. It is a common practice among participants to use different types of naturally occurring or chemically produced psychoactive substances, reportedly to deepen the connection with other people and to enhance the experience of music. The music itself, which includes different sub-styles, is mixed live by DJs using dedicated equipment and is basically composed of synthetic sounds and pre-recorded samples organised in repetitive patterns, similarly to other forms of electronic dance music such as techno, house or drum'n'bass (Cole and Hannan 1997).

Somehow in continuity with the hippie discourse that characterised the context in which psychedelic parties were born, the international psytrance network today allegedly embraces a sort of syncretic spirituality, which freely

[continuation] the term "network," which highlights the existence of a series of actors who don't necessarily live in the same place nor form a well-defined group, but are connected by direct interactions and/or communication technologies and share some common goals and practices. For a critical revision of the use of this term in anthropology, see Castro and Goldman (2012).

5 The concept of "rave party" emerged in relation to clandestine dance music parties held at least since the 80 s in abandoned warehouses in the UK and the US, and was later adopted by many groups linked to different electronic dance music genres and sub-genres, including psytrance. The first and most comprehensive history and analysis of the rave phenomenon and its different manifestations can be found in Reynolds (1998). Psytrance parties worldwide range today from being completely clandestine and unsupervised (e.g. small open air parties in very remote locations, occupied abusively) to totally legal and licensed ones (e.g. big commercial festivals or nights in clubs, with paid tickets and security measures applied). The majority of events though, lies in some kind of middle ground between these two poles (e.g. semi-legalised parties held in private spaces or pieces of land rented for the occasion, eventually without possessing all the permissions/licences needed). 
mixes elements of different religious traditions and meditation practices from all over the world. Similarly, a pacifistic and inclusive ethos is considered to be at the basis of psytrancers' lifestyle, and is expressed through a rhetoric of tolerance and togetherness, revolving around concepts like "unity" and "oneness." An environmental attitude influences practically the organisation of the events, stressing the importance of their sustainability, and could be seen as a consequence of what has been defined as "sacralisation of nature" (see Cardano 1997). The psytrance network shares this conception with other groups devoted to the development of non-urban lifestyles, like the ones connected to permaculture techniques and eco-villages projects (see Lockyer and Veteto 2013), which are not rarely invited to give workshops or lectures at bigger psytrance events. Themes of this kind regularly populate psytrance's textual byproducts and visual imagery, ${ }^{6}$ and represent a central topic of conversation between participants, inside and outside the parties. This whole set of ideas is often referred to in media and online resources as "PLUR philosophy" - the acronym standing for Peace, Love, Unity and Respect and represents a sort of unwritten code of conduct which participants are supposed to follow (Schmidt 2010). ${ }^{7}$

Israel is widely considered - both in the academic discourse and in the opinion of many people within the movement - one of the countries in the world where psytrance attained the highest degree of participation and diffusion. During the 90 s and 2000s, trance music accompanied a process of change in young middle-class people's management of leisure, affecting in particular the generation that grew up after the 1982 Lebanon War. Many young Israeli travellers were present and had an active role in the birth of the trance phenomenon in Goa since its very beginning, and especially after 1988 when, thanks to a series of changes in the Indian-Israeli diplomatic relations, it became easier for them to obtain tourist visas for India (Rubinoff 1995: 502-503). They were mostly young people travelling for some months immediately after the end of compulsory military service. This habit of spending some months travelling after the army, known in Hebrew as tarmila'ut, has become so common and relevant for a large number of middle-class young people in Israel, that it has

6 The names of the artists, the titles of albums and songs, as well as the denominations and descriptions of the events worldwide, offer several examples of this kind, like: Alchemy Circle, Sacred Seed, Return to the Source, Gathering of the Tribes, Earthdance, Rainbow Serpent, etc. Similarly, Indian deities, Buddha images and other symbols from different religious traditions can be found in the design of countless artwork and posters, as well as in the decorations of parties and festivals.

7 PLUR: Peace, Love, Unity, Respect was the title of a sort of informal ravers manifesto, credited to the New York DJ Frankie Bones, which began to circulate freely in the firsts acid house parties in the US and Europe. Passing through Goa it was spontaneously adopted by the global psy network. The full text of the manifesto is accessible from < http://peaceandloveism.com/blog/2009/09/peace-love-unity-and-resp ect-the-ravers-manifesto $>$ (last access in January 2018). 
been regarded as a contemporary rite of passage, subsequent and complementary to the military service (see Noy and Cohen 2005). During the 1990s and the first decade of 2000, India has been one of the most common destinations of these trips (Maoz 2005).

At least since 1990, the first full moon gatherings started to be organised in Israel (St. John 2012a: 238). Similarly to other countries in the world, in Israel psytrance emerged at the beginning as a substantially clandestine and illegal practice, and the first decade of its history was characterised by a remarkable work of repression of the parties by the police, resulting in fines and confiscation of equipment (as shown for example in the documentary Psychedelic Zion by Isri Halpern). This contributed to the creation of an atmosphere of blame and repression around the movement, supported by recurrent media representations of trance events in terms of dangerous and senseless drug parties (Meadan 2006; Schmidt 2010).

This repressive attitude pushed the organisers of events to seek refuge in legally equipped clubs, some of which were nevertheless affected by police raids, or otherwise to locate the events in more and more remote places, reaching the Negev desert, where a lot of clandestine events still take place today. Overall, far from arresting the proliferation of the phenomenon, repression had the paradoxical effect of increasing its popularity and, above all, it had a crucial role in shaping a self-identification for the new-born network (Regev and Seroussi 2004: 183; Carmi 2013b). A series of protest parties were organised, attracting tens of thousands of people and thus immediately becoming some of the biggest psychedelic trance festivals ever held anywhere in the world until then: the festival of Ganei Huga Park in June 1997, provokingly organised in partnership with the Israeli Anti-Drug Authority and called "the drugless festival," in which almost 15,000 people took part, and the Nitzanim beach party on the following September, stopped on the second day by the police in front of about 30,000 people (St. John 2012a: 239; see also the movie Karahana, produced by record label Phonokol). The peak of this process was a demonstration called "Give Trance a Chance," held on the $9^{\text {th }}$ of July 1998, during which 30,000 to 50,000 people (Carmi 2013c) gathered around a big stage mounted in Tel Aviv's city hall square, Rabin square, to "fight for their right to party," as stated by the event's slogan. A similar event called "The Gathering" followed in Jerusalem in 2000 (St. John 2012a: 240).

These events marked a turning point in the history of Israeli psytrance, which since the early 2000s began to be gradually integrated into the musical mainstream and to be represented by the media at all levels. Some producers and DJs, like Astral Projection, California Sunshine, Eyal Barkan, Infected Mushroom, Oforia, Skazi, or Vibe Tribe, began to gain commercial success within the state and internationally, dedicated radio programs were created and dozens of record labels were founded, quickly publishing hundreds of 
records and compilations. Psychedelic trance music became a pervasive background of the most diverse situations of everyday life: bars, restaurants, supermarkets, taxis, buses and even some weddings, and other marks associated to the psychedelic network got more and more common in clothing, media, arts and on the city walls (Regev and Seroussi 2004: 183).

With some minor fluctuations across the years, the level of participation and diffusion of psytrance in Israel has remained considerably high up to the present moment, as evidenced for example by the increase in size of festivals like "Unity," "Neverland" or "Indigo." Another example was the big joint event called "Boom PuriMoksha," a two-day festival organised in 2014 by Moksha Project, one of the main crews of party organisers in Israel, active since 1999, in collaboration with Good Mood Production, the promoters of the Portuguese "Boom" festival, as referred above, one of the biggest psytrance festivals in the world. Moreover, in the same year, the first edition of "Midburn," Israeli regional event of the Burning Man Network, was held in the Negev desert. ${ }^{8}$

\section{INTERPRETATIONS OF THE PHENOMENON}

The life and growth of Israel-born citizens is marked by the experience of prolonged conflict and extended militarisation which characterise the history of the country since its very beginning, something which is usually referred to in Hebrew as ha'matzav, literally "the situation." All citizens, with very few exemptions, are called when turning 18 years old to join the army for a compulsory military service (two years for women, three years for men), during which many of them actually participate in field operations in the West Bank and Gaza. After the service and up to the age of 55, most male citizens living in Israel are still included in the military reserve system, being called for a certain amount of days every year (see Lomsky-Feder and Ben-Ari 1999; Maman, Ben-Ari and Rosenhek 2001). Hence, as pointed out by numerous studies, the army in Israel possesses a very strong practical and symbolic value and the compulsory military service has been listed as a crucial rite of passage that forms and socialises almost all new Israelis, marking the access to full citizenship (see Kanaaneh 2008; Levy and Sasson-Levy 2008). More generally, it can be said that citizens are included in a constant "ritual of security," which

8 "The Burning Man" (BM), held since 1986 in the Black Rock desert in Nevada (US), is an annual gathering consisting on the building of a temporary community where money is banned and cooperation and civic responsibility are encouraged. BM is the biggest and oldest of a series of self-appointed "transformational festivals" (including the "Boom" festival), which promote personal growth through lifestyle changes and different forms of pagan spirituality, often including some form of ecstatic dance and the use of psycho-active substances. Since the early 2000s, regional BurningMan-like events started to take place all around the world, giving birth to the Burning Man Regional Network. See < http://burningman.org/ > (last access in February 2019). 
involves many other aspects of everyday life (Kaplan 2000). It is not surprising then to note that nearly all the interpretations given to explain the exceptional prominence attained by psytrance parties in Israel relate it in some way with the particular condition in which most trancistim grow up.

Since the phenomenon started to gain popularity at the end of the 90s, it has been very common in the Israeli media discourse to consider psytrance parties as a reaction to the pressure caused by the conflict and by the order imposed by the military service. In particular, many journalists identified the 1982 Lebanon war as a turning point, after which many young people would have started to lose faith in the Zionist project, which had supposedly justified the sacrifice for the country until then. Positions of this kind are well represented by the words of Assaf Sagiv (2000), one of the first journalists to extensively comment on trance parties. In his famous article called "Dionysus in Zion" he directly connected the diffusion of these new hedonistic practices to the difficult condition that Israeli youth was facing and that, in his opinion, was no longer supported by a shared ideology:

"The burden Israeli society places upon its youth has played, no doubt, a decisive role in the Dionysian outburst of the past decade. The political, social and economic realities that surround the young Israeli have made him particularly vulnerable to the charms of the god of wine and fertility. However, the response to his call would not have been so overwhelming had Israeli society not failed to provide its young with a viable alternative ethos. The neo-pagan ecstatic revival has filled the vacuum left by the demise of the old Zionism, and has been fuelled by a mistrust felt by many youth towards anything reminiscent of the grandiose slogans and utopian promises of an earlier day" (Sagiv 2000).

The first scholar to investigate on the psytrance phenomenon in the country was the Israeli anthropologist Bryan Meadan, who first published in 2006 the result of his research based on a prolonged ethnographic fieldwork inside psychedelic parties. Also Meadan observes a connection between psytrance and the questioning of the sacrifices and obligations implied by the Zionist project. In particular, the author identifies the heavy media blame and the police repression occurred during the first period of parties in the $90 \mathrm{~s}$ as the main factors that triggered in many trancistim a feeling of detachment from their society, pushing them to question their condition and to seek an alternative identification in the psychedelic network:

"[...] the Zionist identity, which brought them to join combat units or volunteer for extended service in the military, begins to falter and fade. Its significance to the trancists lessens, and the events they experience at the 
parties, particularly the intrusion of the police, raise serious questions regarding their loyalty to the Zionist dream. [...] Since this feeling is so common among the trancists, they develop between themselves tools to enhance this alternative subculture, and therefore strengthen their collective escape from Israeli society. [...] In addition, an ideological worldview stressing 'peace, love, unity and respect' become common slogans within the community, and help provide the trancist with a reason to belong. The world, according to the trancist, is better off with trance" (Meadan 2006: 51-53).

Elinor Carmi, former Israeli psytrancer and now researcher at the Media and Communication department of London's Goldsmiths College, thus expressing more of an insider view on the phenomenon, insists as well on the inseparability between "the situation" and the spreading of psytrance, and eventually considers trance parties in terms of some kind of "therapy treatment":

"Trance culture has answered the deep needs of its audience. The first wave of Trance at the end of the 1980s was formed by young people, twenty something ex-combat units who had just finished the army after the first Intifada. They have experienced horrible things over there, seen their friends being killed, taking part with things they did not necessarily agree with. They were broken and thrown away to citizenship. The military system did not provide them with any mental support, so in fact, Trance culture was a sort of therapy treatment for them: you dance and do not need to talk" (Carmi 2013b).

Similarly, St. John affirms that "militarism has greatly influenced the spectacular abandonment of the self in Israel" (2012a: 237), and that the spread of psychedelic parties could be regarded as a response to the absence of freedoms perceived by young Israelis in comparison to their peers' from Europe and the United States, with whom globalised media have put them in touch. They would then look for these freedoms "in a performed exodus from the pressures of everyday life" (St. John 2012a: 236).

Even if each of these views underlines slightly different aspects of the phenomenon, all of them seem to share the implicit assumption that the participation in psytrance would stand in a relation of opposition with the situation of conflict and militarisation that many young people experience: these interpretations assume that most party goers share the perception of a somehow unfair and wearing life condition, and that the hedonistic practices and pacifistic rhetorics which characterise the parties represent a reaction to that condition, and perform a temporary subversion of it.

At a first look, some simple observations seem to support this idea, and in fact I was myself biased in thinking in a similar way when I first approached 
the object of study. To begin with, following the accounts of numerous of my interlocutors, although some people attend their first parties while still in school, and some other people keep going to parties occasionally as adults, the period of most intense participation to the psychedelic network overlaps with the military service years for the majority of them. ${ }^{9}$ Of course, not all soldiers in service attend psychedelic parties, but the majority of the people who do attend parties are likely to be doing their military service in that same period of their lives. ${ }^{10}$ It is quite common then, travelling through the country, to meet groups of young soldiers leaving their base with the uniform still on to go together to a party during weekends off. Nevertheless, when asked directly about the topic, the majority of trancistim consider their own participation in parties as in some way deviant in relation to a series of values that they assume as normal for Israeli society, and lots of them frequently express some worries of being seen or discovered attending them. ${ }^{11}$ Also, Israeli media still frequently depicts parties and party goers in deviant terms too (Schmidt 2010: 133).

The fact that these two experiences, the military service and the attendance of psychedelic parties, overlap during the life course of many people, with psytrance still considered to be a deviant practice, might apparently justify the assumption of a relation of opposition/subversion between the two things. In addition to this, the idea that trance parties represent an inversion of a daily conflict condition seems to be implicit in the immediate dissonance between the reality of war, soldiering and military occupation and the aforementioned PLUR rhetorics. These themes, which go along with most of the manifestations of the psytrance network worldwide, seem to be actively embraced and reproduced by the organisers and participants of psytrance events in Israel. Several examples of this may be found in textual and visual byproducts of Israeli psytrance, as well as in trancistim's verbal and visual communication: the peace symbols, hindu "Om" or "Peace in the Middle East" recurrently appearing in stickers or clothing; the frequent messages like "spread the love" or "love,

9 This coincidence could be partly justified by the fact that the military service starts with the completion of age (18 years), which is also a mandatory condition to access legal psytrance events, and which makes it easier to attend them in general, given that a car is often required to reach the locations. On the other hand, after the end of the military service, the reduction of participation can be explained with the beginning of a demanding university course, or a professional career.

10 It is not the goal of this research to analyse the composition of the Israeli psychedelic network, but both Meadan (2006) and Schmidt $(2010,2012)$ affirmed that the majority of psytrance party goers seem to come from secular, middle-class, urban environments.

11 This was frequently an issue during the shootings, since several people were understandably worried about being filmed while at the parties. In many occasions, interlocutors were enthusiastic when we approached them at the beginning, but became nervous and hesitant when they realised that they were going to be filmed overtly and started to question us about the outputs of the movie: "Is it going to the television?" 
peace \& harmony" in forums and mailing lists; the constant calls for "all the tribes" to "join the celebration" in the events descriptions, and so on. The very term Moksha in the name of the group of party organisers Moksha Project is deliberately taken from Hinduism, referring to its meaning of liberation, as reported on the crew's website:

"The word 'Moksha' comes from the Sanskrit language. If we had to put it into a one-word-translation it would mean FREEDOM, but in deep it is a level of meditation when body, mind \& soul become one, liberating the spirit from the cycle of death and rebirth - enlightenment. [...] And this is what we want to give you in our events: we try to create the best environment for people to feel this freedom and this contact to their inner selves. [...] There is nothing more we want to see in our events than you, smiling, loving, laughing, dancing, happy with yourself and with the others, our brothers, around you. We invite you to share this dream with us, to come to our events with an open heart, and to help us build this perfect atmosphere, so we all can achieve MOKSHA." ${ }^{12}$

In some cases, the Israeli-Palestinian conflict is directly addressed in this kind of discourse, like for example in the ambitious description of the 2014 event "Boom PuriMoksha", which explicitly presented the party not only in terms of an event bearer of a message of hope and peace, but ultimately as a concrete opportunity to intervene and make a change:

"A special time of the year is approaching... a time of wild celebrations, of renewal and a time for the joyous coming together of communities in many different cultures.

To celebrate this special occasion, Boom will spread its vibe in one of the most unique places in the whole world, where Israel and Palestine meet. In sync with the cheerful celebrations of Purim, in partnership with Moksha Project, the Boom spirit will travel to the heart of the Middle East!

Over the millennia this unique place has seen many different cultures striving to come together. And such an intense convergence of energies makes this place an acupuncture point of the Earth. This is where new information of hope and peace can be inserted, to reach out to the whole planet.

Mind blowing music, psychedelic arts, the principles of sustainability, wild dance will open up the possibility for something new to be born.

Together we will plant the seed of a culture of tolerance, respect, love and togetherness.

All tribes of the world are invited! 
From the heart of it all to all the hearts of the world!

Shalom and Salaam!" 13

Yet, several other elements suggest the existence of very different uses and meanings given to the parties, and some of them have been highlighted by other studies. For instance, examining other textual and verbal contents produced within the network, Israeli anthropologist Joshua Schmidt, who conducted a prolonged ethnographic research within mesibot, observed that a rhetoric completely different from the PLUR one co-exists in the psytrance discourse, revolving around themes that suggest conflict, tension and aggression (Tobin and Schmidt 2012).

Many examples could be found again in names of albums, artists or events: from the title of the famous 1998 album by Eyal Barkan Good Morning Israel (reference to the war movie Good Morning Vietnam by Barry Levinson), to others like Expression of Rage, Psycho Sonic, Deeply Disturbed, Becoming Insane, Smashing the Opponent, Conquering the Israeli Desert, We're Dangerous, We Must Evacuate, Ground Zero, Nu-Clear Visions of Israel, etc. Similar expressions are found in the lyrics (when present), and in what St. John (2012b: 442) indicates as "nano-media": small voice samples taken from movies, documentaries or speech recordings, and inserted by the producers into the music tracks, in a modified but intelligible form. An example could be the single Deeply Disturbed, published in 2003 by the duo Infected Mushrooms (possibly the Israeli psytrance act which met the greatest public success in and out of the country), in which a heavily distorted voice obsessively repeats the verses: "I'm deeply disturbed, and I am deeply unhappy." Similarly, in the case of visual expressions, it can be noticed how, beside the usual themes that characterise the whole psytrance visual imagery, Israeli artworks and designs are filled up by another set of themes, revolving around the symbolism of the nation. Quite uniquely, I believe, among the other local manifestations of the international network, the Israeli flag, and in particular the figure of the Star of David, are revived in dozens of different versions: decomposed in fluorescent fractals, but also transfigured into metallic, camouflage or mechanical structures.

Some interesting considerations are reported by Schmidt (2010, 2012) also in relation to some verbal expressions used by party goers. Within the private communications and mailing lists through which information about the events is disclosed, it is a frequent practice between participants to mutually invite one another to keep the details secret, in order to avoid attracting police and "undesirable elements" (Schmidt 2010: 134-135). Quoting various informal

13 From < http://www.boomfestival.org/boom2014/news/boom-news/boom-purimoksha $>$ (last access in January 2018). 
conversations between trancistim inside and outside the parties, Schmidt observes that the terms used to define these potential undesirable elements are mainly two: arsim and shimonim, as opposed to Anashim yafim (beautiful people). Arsim is the plural of arse, an Arabic word literally translated as "pimp" and used in Hebrew with the meaning of "idiot," with a slightly racist connotation; similarly, shimon is a denigratory way to refer to mizrahim, Israeli Jews of Middle Eastern and North African origins. ${ }^{14}$ Arsim and shimonim would not be welcome because unable to properly connect with the values of the parties and only intentioned to get drunk and look for sexual partners, being therefore prone to generate fights or indulge in sexist behaviour (Schmidt 2010: 136).

What distinguishes the beautiful people from the undesirable elements in the trancistim discourse is not thus an ethnical identification, but the ability to adhere to a specific code of conduct, so that, if a young Ashkenazi behaved improperly, he would still be labeled as arse or shimon (Schmidt 2012: 45). Yet, the use of the terms arsim and shimonim brings with itself the trace of the hegemonic cultural elite who introduced it, remarking who could draw the line between those who know how to behave and those who don't. Moreover, the identification and exclusion of "undesirable elements" on the basis of the respect of a certain code of conduct and their labelling with the subtly racist categories of arse and shimon appear as highly contradictory of the egalitarian and inclusive ethos which is supposed to be at the basis of the psytrance network. Schmidt (2010: 145, 2012: 46) concludes therefore that the psytrance network superficially appears as questioning some of the dominant discourses of Israeli society, but in fact tends to reproduce and reflect some of its fractures and paradoxes. In this sense, he considers psytrance as having been gradually "integrated into the Israeli mainstream," after a prior phase as a clandestine and potentially subversive practice (Schmidt 2012).

\section{A CASE STUDY: THE 2012 PURIM PARTY}

The examples and interpretations reported above seem to show that different uses and meanings are given to psytrance parties by different actors in Israel. In the various expressions produced by the network, different and sometimes contradictory discourses co-exist. Assuming there is a connection between "the situation" and the exceptional spread of psytrance parties seems reasonable, but the idea that psytrance would stand in a relation of opposition/subversion with a daily condition marked by the burden of conflict and soldiering, implicit in many interpretations, appears too simplistic when confronted with

14 On the discrimination of Mizrahi Jews and the Ashkenazi cultural hegemony in Israel, see Giulia Daniele's article in this dossier. 
this plurality of discourses. It seems instead that the experience of conflict and soldiering is sometimes transposed indirectly into the phenomenon on a symbolic level (for example in textual or visual content produced by organisers and musicians).

Eventually, "the situation" can engage physically with parties, which may become targets of terrorist attacks, as in the explosion of the Dolphinarium club in Tel Aviv in 2001, or being hit by a rocket launch, as happened in 2010 at a party on Zikim beach (Schmidt 2012: 42). I present here the analysis of one episode of this kind, to relate the interpretations reported in the previous section with empirical data, and to introduce some of the questions and hypotheses that will be discussed in the last section of this article. ${ }^{15}$

On the night between the $9^{\text {th }}$ and the $10^{\text {th }}$ of March 2012, in occasion of Purim, the group Moksha Project organised a mesiba in which around 2,000 people took part. ${ }^{16}$ The following days became notorious for a series of clashes between Israel and the Gaza Strip, started on that $9^{\text {th }}$ of March with a targeted air strike by the Israeli army, during which a group of militants including Zohair al-Qaisi, general secretary of the Palestinian organisation PRC (Popular Resistance Committees), were murdered, and a dozen civilians lost their lives. A rocket launch from the Strip followed, apparently as a retaliation for the killings. ${ }^{17}$ Through the night several rockets hit the ground just a few hundred meters from the place where the party was taking place (near Mitzpe Gvulot, between Ashkelon and Sderot, close to the Gaza Strip border). Despite the news about the clashes had widely spread before and within the party, the latter began "as expected," as stated by the recorded voice of the info-line, ${ }^{18}$ and continued throughout the night and the morning after. The event would be interrupted in the early afternoon of the next day, ahead of schedule, following the information that the Israeli army would attack the Gaza Strip a few kilometres from there.

15 The sequence of events here presented is a reconstruction based on the account of my interlocutors, one of them being part of the organisation of the party itself. At the time of the events, Alessandro Baltera was in Israel for the first pre-production field research for The Loudest Place on Earth and was involved in the whole situation, filming before, during and the after the party. The footage collected was later edited into the short movie Blessed be Mordechai, Cursed be Haman, produced by BabyDoc Film and presented at various international festivals.

16 Purim is a Jewish holiday that commemorates the salvation of the Jewish people from the persecution of Haman, at the time of Queen Esther of Persia. Many people celebrate it dressing up in costumes at exuberant parties, in a similar way to how Carnival is celebrated in many cities in Europe. 17 See BBC News, "Israel launches deadly air strikes on Gaza," 10 March 2012, available from $<$ https://www.bbc.com/news/world-middle-east-17319054 > (last access in February 2019).

18 In Israel, as in other countries, to avoid the arrival of the police or undesired people, the location of a party is kept secret by the organisers, who share just a telephone number, called info-line. Instructions to reach the place are made available through a recorded voice message just a few hours before the event. 
On the following $23^{\text {rd }}$ of May, the organisers of the party released a video of the event on their YouTube channel, significantly entitled "Purim 2012 - Against All Odds." The video opens with the images of the rocket launch broadcasted by the national news on Channel 2. While the voice-over of the journalist lists the names of the affected towns (including the cities near the location where the party was taking place), a psytrance track slowly increases in volume together with the sound of a helicopter in flight, and the images of the news give way to an aerial shot showing just sand for a few seconds, then rising up revealing the presence of thousands of people and hundreds of tents and cars gathered around the big sound system mounted in the middle of the desert. ${ }^{19}$

Further investigation would be needed before drawing any conclusion, but cases as such seem to suggest that the relation between the daily experience of the conflict and the meaning given to parties by its participants is more complex and ambiguous than it could seem at a first look. From a closer point of view, parties do not appear merely as a reaction of some sort, but as a phenomenon that engages with "the situation" in different senses. In particular, it seems that when episodes linked to the conflict involve a party more closely, participants are faced with it and their choices get deeper implications: the decision to stop or not to stop a party, to stay or to go away, the way things are presented during the party, and the terms used to account the story later, all this attains a political dimension. In the particular context of Israel then, a rave party, something usually depicted by the media worldwide as the expression of a desire to obliterate and subvert a daily life condition, and considered as such by some scholars as well, might become instead an unexpected occasion for participants to think the conflict and to position themselves in relation to it, even if not necessarily through an aware reflection. The participation in a situation that blends the feeling of togetherness given by the party (frequently deepened by the use of psycho-active substances) with the comrade-like solidarity given by the sharing of a potentially dangerous and politically relevant situation, might establish a bond which transcends the psytrance network itself, embracing a broader identification - national, generational, political linked to a particular life condition.

Trance music could then be considered as a central element of this identification and performative practices. Following the accounts of my interlocutors, I suppose that this music actually became the soundtrack of the military years for many young soldiers, not just because of their attendance to parties, but also for being the kind music appearing in their mobile phones and MP3 players, listened to during transfers and training sessions, and perhaps

19 “Moksha Project Presents - Purim 2012 - Against All Odds" (uploaded 23/05/2012), available from < https://www.youtube.com/watch?v=h57aADJLlLg\&t=ls > (last access in February 2019). 
sometimes also during the very military operations (similarly to what has been reported in studies about the US troops in Afghanistan and Iraq - see Pieslak 2009; Sumera 2013). Observing groups of soldiers in uniform dancing together to the rhythm of psytrance in front of their buses parked during a transfer (as I have seen once near Mitzpe Ramon), or on top of their tanks returning from an operation in Gaza (as can be seen in several YouTube videos), ${ }^{20}$ seems to support this hypothesis.

\section{FINAL REMARKS}

As reported above, since its arrival in Israel, psychedelic trance gradually shifted from a relatively small and clandestine movement into a big network with many events happening regularly and a high number of people involved. During the first period of parties in the 1990s, the atmosphere of blame and repression created around the phenomenon contributed to label it as a deviant practice, and eventually triggered a series of protests. Similar struggles happened in many other countries were other illegal rave movements spread, first of all in the UK, were raves were officially banned with the notorious Criminal Justice Act of 1994, followed by massive street demonstrations (see Reynolds 1998). Because young trancistim experienced a very particular life condition marked by the burden of conflict and military obligation, and many of them started to express some kind of disillusion towards the national project that had justified that sacrifice until then, the exceptional spread of psychedelic parties in Israel was initially explained with the assumption that those hedonistic practices and pacifistic discourses were performing a temporary subversion of that condition.

An interpretation of this kind could be comprehensible in relation to the context in which the first parties began to spread, even if a deeper historiographic work would be needed to understand how the relation between the

20 I am aware that the empirical value of a video uploaded on YouTube is highly questionable. However, I think that the presence of a significant quantity of videos on the topic could be seen as interesting data in itself, even without being able to assess the authenticity of its content, which is too relevant not to be at least mentioned in this article. For a reflection on the use of this kind of digital sources in ethnographic research in the Israeli army context, see Stein and Kuntsman (2015). I list here just a few relevant links, related to 2014 operation Tzuk Eitan (Protective Edge) in Gaza: 1. "Israeli soldiers dance psytrance :)" (uploaded 28/07/2014, available from < https://www.youtube. com/watch?v=95jHTgfUCJs >); 2. "IDF Soldier Party 2014" (uploaded 2/08/2014, consulted from $<$ https://www.youtube.com/watch? $\mathrm{v}=\mathrm{dUCPdX} 8 \mathrm{nPCk}>$ ); 3. "Israeli soldiers dancing in Gaza Border. Operation Protective Edge" (uploaded 23/07/2014, available from < https:/www.youtube.com/ watch? $\mathrm{v}=2 \mathrm{hqiKxAhBV8}>$ ); 4. "Israeli soldiers (IDF) party hard - dance disco techno army tanks festival" (uploaded 4/01/2015, available from < https://www.youtube.com/watch?v=40o4B9bcW6g $>$ ); 5. "The NaNach Brigade dancing with IDF Soldiers (July 2014)" (uploaded 25/07/2014, available from < https://www.youtube.com/watch?v=Yk_-bevtqMs >); 6. "Breslev Israel, Emuna Outreach and Operation 'Protective Edge'” (uploaded 22/07/2014, available from < https:/www.youtube.com/ watch? $v=$ uu54gJnv4jw $>$ ). 
military experience and the spread of psytrance developed and changed over time, and to explore any possible connection between the psytrance network and other pacifist movements in Israel and internationally, as well as with other pre-existing youth subcultures.

But the subversion explanation seems too simplistic when applied to the present moment. Taking into account the observations reported above, I suggest instead that there are today various uses of trance music and parties, carried on by different actors, and that distinct discourses co-exist in the network. Parties are now widespread and attended by quite a high number of people, mostly young people who are doing their military service in the meantime; yet, psytrance is still frequently depicted by the media and considered by participants themselves as a deviant practice. It still conveys a discourse akin to the aforementioned PLUR rhetoric, while at the same time other themes and images populate the various expressions of the network.

In this sense, I think that the psytrance phenomenon and "the situation" interact in a more complex and ambiguous way: parties do not just perform a subversion of the conflict scenario but can also be themselves charged with a political value, especially when episodes linked to the military occupation intersect indirectly with them, apparently triggering an identification that transcends psytrance itself. Consequently, the different expressions of the psytrance network (verbal, visual, etc.) seem to incorporate symbolic elements linked to war and militarisation, and trance music itself seems to have become the soundtrack to these experiences for many young soldiers.

At this respect, it would be crucial to better investigate the relation between the Israeli psytrance network and the growing but still little explored Palestinian rave movement. The only study on the topic which I am aware of at the present time, by Karkabi (2013), seems to suggest that these raves are no less invested of a political value and that Palestinian ravers do participate occasionally in parties in the Israeli side of the border. Exploring the dynamics of these encounters and the historical and geo-political processes underlying the development of the two movements would help to better understand how psychedelic trance music may be connected to a political or national discourse, with different purposes, in the context of conflict. 


\section{REFERENCES}

CARDANO, Mario, 1997, Lo Specchio, la Rosa e il Loto: Uno Studio sulla Sacralizzazione della Natura. Roma, Seam.

CARMI, Elinor, 2013a, TranceMission: The Penetration of the Psytrance Culture into Israel between 1989-1999. Tel Aviv, Resling [in Hebrew].

CARMI, Elinor, 2013b, "Ma'ariv interview", retrived from Pinkeee, < http://www.pinkeee.co $\mathrm{m} / \mathrm{p}=984>$ (last access in January 2018).

CARMI, Elinor, 2013c, "Reflections 15 years after Give Trance a Chance demonstration", retrived from Pinkeee, $<$ http://www.pinkeee.com/?p=1080 > (last access in January 2018).

CASTRO, Eduardo Viveiros de, and Marcio GOLDMAN, 2012, "Introduction to post-social anthropology: networks, multiplicities, and symmetrisations", HAU: Journal of Ethnographic Theory, 2 (1): 421-433.

COLE, Fred, and Michael HANNAN, 1997, "Goa trance”, Perfect Beat: The Pacific Journal of Research into Contemporary Music and Popular Culture, 3: 1-14.

GRISTINA, Giorgio, 2015, The Chosen (Party) People: Young Israelis' Paths through Psychedelia, the Military and the "East". Torino, Università degli Studi di Torino, MA dissertation.

KANAANEH, Rhoda, 2008, Surrounded: Palestinian Soldiers in the Israeli Military. Stanford, Stanford University Press.

KAPLAN, Danny, 2000, “The military as a second bar mitzvah: combat service as initiation to Zionist masculinity", in Mai Ghoussoub and Emma Sinclair-Webb (eds.), Imagined Masculinities: Male Identity and Culture in the Modern Middle East. London, Saqi Books, 127-144.

KARKABI, Nadeem, 2013, "Staging particular difference: politics of space in the Palestinian alternative music scene”, Middle East Journal of Culture and Communication, 6: 308-328.

LEVY, Gal, and Orna SASSON-LEVY, 2008, "Militarized socialization, military service, and class reproduction: the experiences of Israeli soldiers", Sociological Perspectives, 51 (2): 349-374.

LOCKYER, Joshua, and James R. VETETO (eds.), 2013, Environmental Anthropology Engaging Ecotopia: Bioregionalism, Permaculture, and Ecovillages. New York, Berghahn Books.

LOMSKY-FEDER, Edna, and Eyal BEN-ARI (eds.), 1999, The Military and Militarism in Israeli Society. Albany, State University of New York Press.

MAMAN, Daniel, Eyal BEN-ARI, and Zeev ROSENHEK, 2001, Military, State, and Society in Israel: Theoretical and Comparative Perspective. New Brunswick, Transaction.

MAOZ, Darya, 2005, "Young adult Israeli backpackers in India", in Chaim Noy and Erik Cohen (eds.), Israeli Backpackers: From Tourism to Rite of Passage. Albany, State University of New York Press, 1 15-145.

MEADAN, Bryan, 2006, TRANCENational ALIENation: Trance Music Culture, Moral Panics and Transnational Identity in Israel. Self-publishing e-book available at Lulu $(<$ https://www. lulu.com/ >).

NOY, Chaim, and Erik COHEN (eds.), 2005, Israeli Backpackers: From Tourism to Rite of Passage. Albany, State University of New York Press.

PIESLAK, Jonathan, 2009, Sound Targets: American Soldier and Music in the Iraq War. Bloomington, Indiana University Press.

REGEV, Motti, and Edwin SEROUSSI, 2004, Popular Music and National Culture in Israel. Berkeley, University of California Press. 
REYNOLDS, Simon, 1998, Energy Flash: A Journey through Rave Music and Dance Culture. London, Picador/Macmillan.

RUBINOFF, Arthur G., 1995, "Normalization of India-Israel relations: stillborn for forty years", Asian Survey, 35 (5): 487-505.

SAGIV, Assaf, 2000, "Dionysus in Zion", Azure: Ideas for the Jewish Nation, 9: 155-178, available from < http://azure.org.il/include/print.php?id $=289>$ (last access in February 2019).

SCHMIDT, Joshua I., 2010, “(En)Countering the beat: paradox in Israeli psytrance”, in Graham St. John (ed.), The Local Scenes and Global Culture of Psytrance. London/New York, Routledge, 131-148.

SCHMIDT, Joshua I., 2012, "Full penetration: the integration of psychedelic electronic dance music and culture into the Israeli mainstream", Dancecult: Journal of Electronic Dance Music Culture, 4 (1): 38-64.

ST. JOHN, Graham, 2004, Rave Culture and Religion. New York, Routledge.

ST. JOHN, Graham (ed.), 2010, The Local Scenes and Global Culture of Psytrance. London/New York, Routledge.

ST. JOHN, Graham, 2012a, Global Tribe: Technology, Spirituality and Psytrance. London, Equinox.

ST. JOHN, Graham, 2012b, "Freak media: vibe tribes, sampledelic outlaws and Israeli psytrance”, Continuum: Journal of Media \& Cultural Studies, 26 (3): 437-447.

STEIN, Rebecca L., and Adi KUNTSMAN, 2015, Digital Militarism: Israel's Occupation in the Social Media Age. Stanford, Stanford University Press.

SUMERA, Matthew, 2013, "The soundtrack to war", in Neil L. Whitehead e Sverker Finnström (eds.), Virtual War and Magical Death: Technologies and Imaginaries for Terror and Killing. Durham, Duke University Press.

TOBIN, Yishai, and Joshua SCHMIDT, 2012, "Comparing and contrasting the behavior and language at secular versus religious trance parties in Israel", in Malka Muchnik and Tsvi Sadan (Tsuguya Sasaki), Studies in Modern Hebrew and Jewish Linguistics Presented to Ora (Rodrigue) Schwarzwald. Jerusalem, Carmel, 519-539.

WILliS, Paul E., 2014 [1978], Profane Culture. Princeton, Princeton University Press.

Receção da versão original / Original version

Receção da versão revista / Revised version

Aceitação / Accepted
$2016 / 12 / 12$

$2018 / 02 / 23$

$2018 / 07 / 25$ 